\title{
New data on the ecology and geographic distribution of Saguinus inustus Schwarz, 1951 (Primates, Callitrichidae)
}

\author{
Valsecchi, J. ${ }^{\mathrm{a} *}$, Vieira, TM. ${ }^{\mathrm{a}}$, Silva Júnior, JS. ${ }^{\mathrm{b}}$, Muniz, ICM. ${ }^{\mathrm{b}}$ and Avelar, AA. ${ }^{\mathrm{b}}$ \\ anstituto de Desenvolvimento Sustentável Mamirauá - IDSM, \\ Av. Brasil 197, Juruá, CP 38, CEP 69470-000, Tefé, AM, Brazil \\ ${ }^{b}$ Museu Paraense Emílio Goeldi - MPEG \\ *e-mail: joao.valsecchi@mamiraua.org.br \\ Recived July 15, 2008 - Accepted June 30, 2009 - Distributed May 31, 2010
}

(With 1 figure)

\begin{abstract}
Saguinus inustus (Schwarz, 1951) is one of the neotropical primates least studied. The distribution of the species ranges from the north of the Solimões River, between the Negro and Japurá Rivers in Brazil, and Guayabero-Guaviare Rivers in Colombia. Nevertheless, due to the low number of specimens collected from the lower Japurá and lower Negro Rivers areas, the geographic distribution is so far poorly delineated. In this study, field data was composed of sightings and the collection of specimens during a survey of mammal diversity in the Amana Sustainable Development Reserve (ASDR). For this survey, two 40-day expeditions were carried out in 2004. The first one occurred during the flooded season in June and July, and the second was during the peak of the dry season in October. Direct sightings were made through hiking along transects, navigation along water channels with a 30-hp speedboat, and gliding along flooded trails in the forest. New records of S. inustus were made in 11 different localities in ASDR. The study has confirmed the presence of the species in the Amanã area, carrying out the first records of the species in flooded forest habitats.
\end{abstract}

Keywords: Saguinus inustus, flooded forests, Amazônia, Amanã reserve.

\section{Novos dados sobre a ecologia e distribuição geográfica de Saguinus inustus Schwarz, 1951 (Primates, Callitrichidae)}

\begin{abstract}
Resumo
Saguinus inustus (Schwarz, 1951) é um dos primatas neotropicais menos estudados. No Brasil, a espécie ocorre ao norte do Rio Amazonas entre os Rios Negro e Japurá (Caquetá), e Guayabero-Guaviare na Colômbia. No entanto, devido ao pequeno número de espécimes coletados entre o baixo Japurá e o baixo Negro a distribuição geográfica é mal delineada. No presente estudo, os dados de campo são compostos por observações e coletas realizadas durante o levantamento da diversidade de mamíferos da Reserva de Desenvolvimento Sustentável Amanã (RDSA). Para este levantamento, duas expedições de 40 dias foram realizadas em 2004. A primeira ocorreu durante a estação da cheia em junho e julho, e a segunda durante o pico da estação seca em outubro. Observações diretas foram feitas através de deslocamentos a pé em transecções, de lancha $30 \mathrm{hp}$ ao longo de cursos d'água, e de canoas durante a cheia na área de várzea. Novos registros de $S$. inustus foram realizados em 11 diferentes localidades na RDSA. Este estudo confirmou a presença da espécie em Amanã, realizando os primeiros registros da espécie em florestas alagadas.
\end{abstract}

Palavras-chave: Saguinus inustus, primatas, Amazônia, Amanã.

\section{Introduction}

Saguinus inustus (Schwarz, 1951) is one of the least studied Neotropical primates. According to the literature, the species has been found in only 16 sites (Hershkovitz, 1977; Hernández-Camacho and Defler, 1993; Barnett et al., 2002; Defler, 1983, 2004; Iwanaga, 2004; Palácios et al., 2004; Souza, et al. 2004) and only 16 individuals have been deposited in scientific collections. The distribution of the species ranges from the north of the Solimões Rivers, between the Negro and Japurá Rivers in Brazil, and Guayabero-Guaviare Rivers in Colombia (Hershkovitz, 1977; Hernández-Camacho and Defler, 1993; Defler, 2004; Souza et al., 2004). Nevertheless, due to the low number of specimens collected from the lower Japurá and lower Negro Rivers areas, the geographic distribution is so far poorly delineated.

In 1980, Rylands (unpubl., reported in Barnett et al., 2002) carried out the first record of the species in the Amanã Sustainable Development Reserve (ASDR) area, 
sighting a group of $S$. inustus along the north margin of Amanã lake. Iwanaga (2004) confirmed through local reports the presence of the species in two localities of the Jaú National Park: the "Janela Monteiro" site and the "Janela Floresta", both along the Jaú River.

Souza et al. (2004) collected a male adult killed by local residents of the Boa Esperança community, located at Amanã lake (02 28'12" S and 64'44' 27' W), and deposited it at Mamirauá Institute's collection (IDSMasto-001). Souza et al. (2004) also observed groups of the species in terra-firme forest, close to the community area. Souza et al.'s observations were made at the opposite margin of that of the recordings carried out by Rylands (Barnett et al., 2002).

All sightings of $S$. inustus described in literature were made in terra-firme forest (Defler, 1983; HernándezCamacho and Defler, 1983; Barnett et al., 2002; Iwanaga, 2004; Souza et al., 2004). The aim of this study is to update the information on the geographic distribution and use of habitat by $S$. inustus, reporting new occurrences and sightings in habitats different from those recorded in literature.

\section{Methods}

Secondary data was obtained through literature review (Hershkovitz, 1977; Hernández-Camacho and Defler, 1991; Barnett et al., 2002; Defler, 1983; 2004; Iwanaga, 2004; Palácios et al., 2004; Souza et al., 2004) and records of Brazilian scientific collections (IDSM and MPEG). Field data was composed by sightings and collection of specimens during a survey of mammal diversity in the ASDR (IBAMA n'. 086/2004 - CGFAU/LIC). For this survey, two 40-day expeditions were carried out in 2004. The first one occurred during the flooded season in June and July, and the second was during the peak of the dry season in October. Direct sightings were made through hiking along transects, navigation along water channels with a 30-hp speedboat, and gliding along flooded trails in the forest.

Two monitoring trails were opened: the Ubim trail located on the left margin of Ubim creek at the left bank of Amanã lake (02 $30^{\circ} 37^{\prime \prime} \mathrm{S}$ and $64^{\circ} 36^{\prime} 40^{\prime}$ ' W), and the Bacaba trail on the right margin of Amanã lake ( $2^{\circ} 30^{\prime} 37^{\prime \prime} \mathrm{S}$ and $\left.64^{\circ} 36^{\prime} 40^{\prime} \mathrm{W}\right)$. Using line transect sampling methods (Emmons, 1984; Buckland et al., 1993) observations were made about group size and habitat use. Stomach and bowel contents of specimens collected were deposited in the Mamirauá Institute scientific collection, whereas furs, skulls and skeletons were deposited in the MPEG. Two individuals were later donated to IDSM. Tissues for DNA extraction were deposited in the Universidade Federal do Pará, Molecular Biology Laboratory.

\section{Results and Discussion}

New records of $S$. inustus were made in 11 different localities in ASDR (Figure 1, Table 1). Two sites were lo- cated on the vicinities of Amanã lake, at the Juá Grande/ Jaquirana creek (2०28' $11^{\prime \prime} \mathrm{S}$ and $\left.64^{\circ} 49^{\prime} 33^{\prime \prime} \mathrm{W}\right)$ and Urucurana, Boa Esperança community (02 $22^{\circ} 07^{\prime}$ S and $64^{\circ} 44^{\prime} 53^{\prime \prime} \mathrm{W}$ ), characterising terra firme and igapó habitats. Two other collection sites were located at the Coraci sector, one near Nova Canaã community, on the margins of Coracizinho River ( $02^{\circ} 35^{\prime} 27.4^{\prime \prime} \mathrm{S}$, and $64^{\circ} 53^{\prime} 10,6^{\prime \prime} \mathrm{W}$ and $02^{\circ} 35^{\prime} 42.4^{\prime \prime} \mathrm{S}$ and $64^{\circ} 52^{\prime}$ ' 56.7' $\mathrm{W}$ ), and the other on São Bento channel $\left(02^{\circ} 37^{\prime} 36.0^{\prime \prime} \mathrm{S}\right.$ and $\left.64^{\circ} 51^{\prime} 57.7^{\prime} \mathrm{W}\right)$, characterising várzea habitats.

Collections were made along Juá Grande creek, in terra firme and igapó habitats, near Boa Esperança community. Three observations were made in flooded areas in ASDR, two in várzea forests on the margin of Coracizinho Rivers, and another one on Bacaba trail, in igapó forest. Three observations were made in terra firme forest, in monitoring trails (one group was observed in Ubim trail, and two other groups were observed in Bacaba trail). Other records came from observations on trails located near Boa Esperança community (02 44' 43' S and 64 33' 26' W), Bom Jesus do Baré community $\left(02^{\circ} 28^{\prime} 37^{\prime \prime} \mathrm{S}\right.$ and $\left.64^{\circ} 42^{\prime} 30^{\prime \prime} \mathrm{W}\right)$, Belo Monte community ( $02^{\circ} 44^{\prime} 33^{\prime \prime} \mathrm{S}$ and $\left.64^{\circ} 33^{\prime} 26^{\prime \prime} \mathrm{W}\right)$, São José do Urini community $\left(02^{\circ} 43^{\prime} 47^{\prime}\right.$ ' S and $\left.64^{\circ} 44^{\prime} 53^{\prime \prime} \mathrm{W}\right)$, Boa Vista do Calafate community $\left(02^{\circ} 39^{\prime} 35^{\prime \prime} \mathrm{S}\right.$ and $\left.64^{\circ} 36^{\prime} 23^{\prime \prime} \mathrm{W}\right)$ and Nova Jerusalém community $\left(02^{\circ} 49^{\prime} 12^{\prime \prime} \mathrm{S}\right.$ and $\left.64^{\circ} 37^{\prime} 07^{\prime \prime} \mathrm{W}\right)$.

Not much difference was observed between male and female sizes collected in ASDR (Table 2). Females were $4.5 \%$ taller and $2.5 \%$ heavier than males. Only two males were collected and their weight and length did not differ from those collected by Souza et. al. (2004) (TL $670 \mathrm{~g}, \mathrm{n}=1$ ).

Four groups were sighted on monitoring trails, three in terra firme forest and one in igapó forest, on the right margin of Amanã lake (Table 3). These groups were composed of two, three, and four individuals (2.75 average, $\mathrm{n}=4$, sd $=0.96$ ). Due to the small number of sightings on monitoring trails, it was not possible to estimate abundance of the species in the area. Nevertheless, it seems that groups sighted at Amanã were smaller from those sighted in the Caquetá Rivers region, in Colombia. In that area, Palacios et al. (2004) sighted groups that varied from three to eleven individuals (06 average, $\mathrm{n}=5$, $\mathrm{sd}=2.7$ ), and Defler (2004) reported the existence of groups with three, seven and eight individuals.

Two out of four groups sighted were in association with double-toothed kites (Harpagus bidentatus). Although local people affirmed that these birds follow S. inustus to predate them, field sightings suggested foraging associations. This avian species is predominantly insectivorous, but may also feed from small vertebrates (Fontaine 1980; Boinski and Scott, 1988). Previous records show that insectivorous birds may benefit from association with primates, capturing prey trying to escape from predation. This behaviour helps them catch previously inaccessible prey, raising foraging efficiency and protection against other predators (Boinski and 

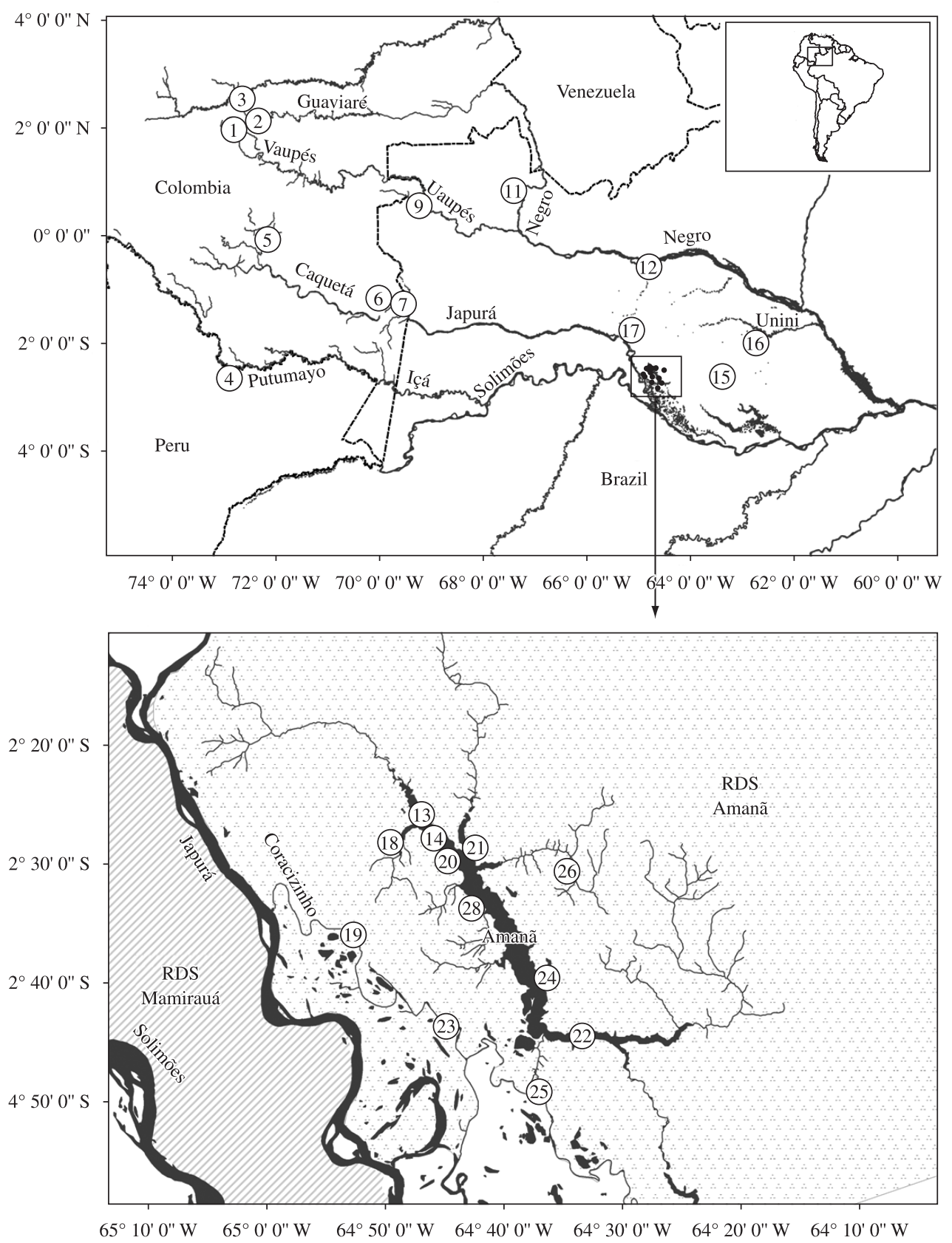

Figure 1. Geographical distribution of the Saguinus inustus specimens. See Table 1 for information on each of the records.

Scott, 1988; Egler, 1991). This type of association has been observed in other species of Saguinus (Egler, 1991; Haymann, 1992) and other genus of primates (Greenlaw, 1967; Fontaine 1980; Boinski and Scott, 1988; Marsh, 2004; Hankerson, 2006).

Saguinus inustus is categorised as least concern in the IUCN red list (2009), but in Amanã the species is relatively abundant, often sighted around manioc gardens and in transects for biodiversity monitoring. No hunting event was recorded for the species, and local people af- firm that $S$. inustus is not hunted for subsistence due to one of its characteristics - its low weight. The species is, nevertheless, used as a pet, and in some rare cases it is commercialised, as observed by Souza et. al. (2004).

\section{Conclusions}

Although this study has almost doubled the number of records of $S$. inustus, much more data is needed to better understand its geographical distribution. The study has confirmed the presence of the species in the Amanã 
Table 1. Update of records of Saguinus inustus.

\begin{tabular}{|c|c|c|c|}
\hline Localities & Coordinates & Habitats & References \\
\hline $\begin{array}{l}\text { 1. Colombia, Alto Caño Itilla, } \\
\text { upper Río Vaupés }\end{array}$ & $2^{\circ} \mathrm{N}$ and $72^{\circ} 47^{\prime} \mathrm{W}$ & - & $\begin{array}{l}\text { Hershkovitz, 1977; } \\
\text { Hernández-Camacho and Defler, } 1983 .\end{array}$ \\
\hline $\begin{array}{l}\text { 2. Colombia, Caño Grande, } \\
\text { upper Río Inírida }\end{array}$ & $\begin{array}{l}2^{\circ} 10^{\prime} \mathrm{N} \text { and } \\
72^{\circ} 20^{\prime} \mathrm{W}\end{array}$ & - & $\begin{array}{l}\text { Hershkovitz, 1977; } \\
\text { Hernández-Camacho and Defler, } 1983 .\end{array}$ \\
\hline 3. Colombia, San José del Guaviare & $\begin{array}{l}2^{\circ} 34^{\prime} \mathrm{N} \text { and } \\
72^{\circ} 39^{\prime} \mathrm{W}\end{array}$ & - & $\begin{array}{l}\text { Hershkovitz, 1977; } \\
\text { Hernández-Camacho and Defler, } 1983 .\end{array}$ \\
\hline $\begin{array}{l}\text { 4. Colombia, Angostura, right marging of } \\
\text { Guayabero River, Guaviare }\end{array}$ & $\begin{array}{l}2^{\circ} 34^{\prime} 31^{\prime \prime} \mathrm{S} \text { and } \\
72^{\circ} 52^{\prime} 57^{\prime \prime} \mathrm{W}\end{array}$ & Terra Firme & Hernández-Camacho and Defler, 1983. \\
\hline $\begin{array}{l}\text { 5. Colombia, Cano Yaviya, } \\
\text { Yarí River, Caquetá }\end{array}$ & $\begin{array}{l}0^{\circ} 00^{\prime} 10^{\prime \prime} \mathrm{S} \text { and } \\
72^{\circ} 11^{\prime} 58^{\prime \prime} \mathrm{W}\end{array}$ & Terra Firme & Hernández-Camacho and Defler, 1983. \\
\hline 6. Colombia, Mirití-Paraná River, Amazonas & $\begin{array}{l}01^{\circ} 11^{\prime} 44^{\prime \prime} \mathrm{S} \text { and } \\
69^{\circ} 533^{\prime} 26^{\prime \prime} \mathrm{W}\end{array}$ & Terra Firme & $\begin{array}{c}\text { Defler, 1983; } \\
\text { Hernández-Camacho and Defler, } 1983 .\end{array}$ \\
\hline $\begin{array}{l}\text { 7. Colombia, vicinity of Comeyafú, } 19,000 \text {-ha } \\
\text { indigenous reserve on the left margin of the } \\
\text { Río Caquetá in the state of Amazonas }\end{array}$ & $\begin{array}{l}1^{\circ} 17^{\prime} \mathrm{S} \text { and } \\
69^{\circ} 34^{\prime} \mathrm{W}\end{array}$ & Terra Firme & Palácios et al., 2004. \\
\hline $\begin{array}{l}\text { 8. Brazil, Amazonas, Provação Santa Cruz, } \\
\text { Igarapé Turi, right bank Rio Papuri (Uaupés) }\end{array}$ & $\begin{array}{l}0^{\circ} 38^{\prime} \mathrm{N} \text { and } \\
69^{\circ} 22^{\prime} \mathrm{W}\end{array}$ & - & Hershkovitz, 1977; MPEG-8789 \\
\hline $\begin{array}{l}\text { 9. Brazil, Amazonas, Mouth of Papuri River, } \\
\text { Rio Uaupés }\end{array}$ & $\begin{array}{l}0^{\circ} 36^{\prime} \mathrm{N} \text { and } \\
69^{\circ} 13^{\prime} \mathrm{W}\end{array}$ & - & Hershkovitz, 1977 \\
\hline $\begin{array}{l}\text { 10. Brazil, Amazonas, Uaupés River; } \\
\text { opposite side of Tahuapunta; }\end{array}$ & $\begin{array}{l}0^{\circ} 36^{\prime} \mathrm{N} \text { and } \\
69^{\circ} 11^{\prime} \mathrm{W}\end{array}$ & - & Hershkovitz, 1977 \\
\hline 11. Brazil, Amazonas, Tabocal, Negro River & $0^{\circ} 48^{\prime} \mathrm{N}$ and $67^{\circ} 14^{\prime} \mathrm{W}$ & - & Hershkovitz, 1977 \\
\hline 12. Brazil, Amazonas, Jaúanari & $0^{\circ} 32^{\prime} \mathrm{S}$ and $64^{\circ} 49^{\prime} \mathrm{W}$ & - & Hershkovitz, 1977 \\
\hline $\begin{array}{l}\text { 13. Brazil, Amazonas, on the } \\
\text { north margin of Amanã lake. }\end{array}$ & - & Terra Firme & Barnett et al., 2002 \\
\hline $\begin{array}{l}\text { 14. Brazil, Amazonas, Near Boa } \\
\text { Esperança community }\end{array}$ & $\begin{array}{l}02^{\circ} 28^{\prime} 12^{\prime \prime} \mathrm{S} \text { and } \\
64^{\circ} 44^{\prime} 27^{\prime \prime} \mathrm{W}\end{array}$ & Terra Firme & Souza et al., 2004 \\
\hline $\begin{array}{l}\text { 15. Brazil, Amazonas, Janela Monteiro - } \\
\text { Parque Nacional do Jaú }\end{array}$ & $\begin{array}{l}02^{\circ} 36^{\prime} 22^{\prime \prime} \mathrm{S} \text { and } \\
63^{\circ} 21^{\prime} 27^{\prime \prime} \mathrm{W}\end{array}$ & Terra Firme & Iwanaga, 2004 \\
\hline $\begin{array}{l}\text { 16. Brazil, Amazonas, Janela Floresta - } \\
\text { Parque Nacional do Jaú }\end{array}$ & $\begin{array}{l}01^{\circ} 58^{\prime} 24^{\prime \prime} \mathrm{S} \text { and } \\
62^{\circ} 43^{\prime} 19^{\prime} \mathrm{W}\end{array}$ & Terra Firme & Iwanaga, 2004 \\
\hline $\begin{array}{l}\text { 17. Brazil, Amazonas, Maraã, } \\
\text { Maguari, on the left margin or Japurá River. }\end{array}$ & $\begin{array}{l}1^{\circ} 50^{\prime} \mathrm{S} \text { and } \\
65^{\circ} 12^{\prime} \mathrm{W}\end{array}$ & - & MPEG: 21840 \\
\hline $\begin{array}{l}\text { 18. Brazil, Amazonas, } \\
\text { Igarapé Juá Grande / } \\
\text { Jaquirana, Amanã Reserve. }\end{array}$ & $\begin{array}{l}02^{\circ} 28^{\prime} 11^{\prime \prime} \mathrm{S} \text { and } \\
64^{\circ} 49^{\prime} 33^{\prime \prime} \mathrm{W}\end{array}$ & - & $\begin{array}{c}\text { This study: MPEG } 36621 ; 36622 ; \\
36623 ; 36626 ; 36627 ; 36628 ; 36632 \\
\text { e } 36633 .\end{array}$ \\
\hline $\begin{array}{l}\text { 19. Brazil, Amazonas, } \\
\text { Margins of Coracizinho River, } \\
\text { Amanã Reserve. }\end{array}$ & $\begin{array}{l}02^{\circ} 35^{\prime} 27.4^{\prime \prime} \mathrm{S} \text { and } \\
64^{\circ} 53^{\prime} 10.6^{\prime \prime} \mathrm{W} \\
02^{\circ} 35^{\prime} 42.4 " \mathrm{~S} \text { and } \\
64^{\circ} 52^{\prime} 56.7^{\prime \prime} \mathrm{W}\end{array}$ & - & This study (sighting) \\
\hline $\begin{array}{l}\text { 20. Brazil, Amazonas, } \\
\text { Boa Esperança community }\end{array}$ & $\begin{array}{l}02^{\circ} 44^{\prime} 43^{\prime \prime} \mathrm{S} \text { and } \\
64^{\circ} 33^{\prime} 26^{\prime \prime} \mathrm{W}\end{array}$ & - & This study (sighting) \\
\hline $\begin{array}{l}\text { 21. Brazil, Amazonas, } \\
\text { Bom Jesus do Baré community. }\end{array}$ & $\begin{array}{l}02^{\circ} 28^{\prime} 37^{\prime \prime} \mathrm{S} \text { and } \\
64^{\circ} 42^{\prime} 30^{\prime \prime} \mathrm{W}\end{array}$ & - & This study (sighting) \\
\hline $\begin{array}{l}\text { 22. Brazil, Amazonas, } \\
\text { Belo Monte community. }\end{array}$ & $\begin{array}{l}02^{\circ} 44^{\prime} 33^{\prime \prime} \mathrm{S} \text { and } \\
64^{\circ} 33^{\prime} 26^{\prime \prime} \mathrm{W}\end{array}$ & - & This study (sighting) \\
\hline $\begin{array}{l}\text { 23. Brazil, Amazonas, } \\
\text { São José do Urini community. }\end{array}$ & $\begin{array}{l}02^{\circ} 43^{\prime} 47^{\prime \prime} \mathrm{S} \text { and } \\
64^{\circ} 44^{\prime} 53^{\prime \prime} \mathrm{W}\end{array}$ & - & This study (sighting) \\
\hline $\begin{array}{l}\text { 24. Brazil, Amazonas, } \\
\text { Boa Vista do Calafate community. }\end{array}$ & $\begin{array}{l}02^{\circ} 39^{\prime} 35^{\prime \prime} \mathrm{S} \text { and } \\
64^{\circ} 36^{\prime} 23^{\prime \prime} \mathrm{W}\end{array}$ & - & This study (sighting) \\
\hline $\begin{array}{l}\text { 25. Brazil, Amazonas, } \\
\text { Nova Jerusalém community. }\end{array}$ & $\begin{array}{l}02^{\circ} 49^{\prime} 12^{\prime \prime} \mathrm{S} \text { and } \\
64^{\circ} 37^{\prime} 07^{\prime \prime} \mathrm{W}\end{array}$ & - & This study (sighting) \\
\hline $\begin{array}{l}\text { 26. Brazil, Amazonas, UBIM transect, } \\
\text { on the right margin of Igarapé Ubim. }\end{array}$ & $\begin{array}{l}2^{\circ} 30^{\prime} 37^{\prime \prime} \mathrm{S} \text { and } \\
64^{\circ} 34^{\prime} 41^{\prime \prime} \mathrm{W}\end{array}$ & Terra Firme & This study (sighting) \\
\hline 27. Brazil, Amazonas, BACABA 01 transect. & $\begin{array}{l}2^{\circ} 33^{\prime} 54^{\prime \prime} \mathrm{S} \text { and } \\
64^{\circ} 42^{\prime} 17^{\prime \prime} \mathrm{W}\end{array}$ & Terra Firme & This study (sighting) \\
\hline 28. Brazil, Amazonas, BACABA 02 transect. & $\begin{array}{l}2^{\circ} 33^{\prime} 32^{\prime \prime} \mathrm{S} \text { and } \\
64^{\circ} 42^{\prime} 44^{\prime \prime} \mathrm{W}\end{array}$ & Igapó & This study (sighting) \\
\hline
\end{tabular}


Table 2. General characteristics of specimens collected in Amanã Sustainable Development Reserve.

\begin{tabular}{cclccc}
\hline Specimens collected & Date & Sex & TL $(\mathbf{m m})$ & CC $(\mathbf{m m})$ & Weight $(\mathbf{g})$ \\
\hline MPEG 36621 & $13 / 6 / 2004$ & female & 681 & 407 & 650 \\
MPEG 36622 & $13 / 6 / 2004$ & female & 633 & 381 & 550 \\
MPEG 36623* & $13 / 6 / 2004$ & female & 602 & 374 & 400 \\
MPEG 36628 & $14 / 6 / 2004$ & female & 635 & 380 & 530 \\
MPEG 36632 & $14 / 6 / 2004$ & female & 625 & 380 & 440 \\
MPEG 36633* & $15 / 6 / 2004$ & female & 656 & 407 & 560 \\
MPEG 36626 & $14 / 6 / 2004$ & male & 590 & 343 & 510 \\
MPEG 36627 & $14 / 6 / 2004$ & male & 630 & 370 & 560 \\
Averages o & & & 610.00 & 356.50 & 535.00 \\
Averages + & & & 638.67 & 388.17 & 521.67 \\
\hline
\end{tabular}

* Fur donated to the Mamirauá Institute collection.

Table 3. Groups of $S$. inustus sighted in monitoring transects.

\begin{tabular}{cccc}
\hline Group \# & Transect & Habitat & \# of individuals \\
\hline 1 & Ubim & Terra firme & 03 \\
2 & Bacaba 01 & Terra firme & 04 \\
3 & Bacaba 02 & Igapó & 02 \\
4 & Bacaba 01 & Terra firme & 02 \\
\hline
\end{tabular}

area, carrying out the first records of the species in flooded forest habitats. The expected geographic distribution of the species covers $23,464,000$ ha, $61 \%$ of which are protected, either in indigenous land or protected areas (Figure 1). The assumption that it occurs along all lower Japurá-Negro interfluve remains to be confirmed. The correct delimitation of its range is of fundamental importance for its conservation. Further studies are urgently needed to assess the status of S. inustus, besides longterm research on its ecology and behaviour.

\section{References}

BARNETT, AA., BORGES, SH., CASTILHO, CV., NERI, FM. and SHAPLEY, RL., 2002. Primates of the Jaú National Park, Amazonas, Brazil. Neotropical Primates, vol. 10, no. 2, p. $65-70$.

BOINSKI, S. and SCOTT, PE., 1988. Association of birds with monkeys in Costa Rica. Biotropica, vol. 20, no. 2, p. 136-143.

BUCKLAND, ST., ANDERSON, DR., BURNHAM, KP. and LAAKE, JL., 1993. Distance 4.0 distance sample: estimating abundance of biological population. London: Champman and Hall.

DEFLER, TR., 1983. Observaciones sobre los primates del bajo Mirita-Paraná, Amazonas, Colombia. Lozania, vol. 46, p. 1-13.

DEFLER, TR., 2004. Primates of Colombia. Bogotá: Conservation International. (Conservation International Tropical Field Guide Series).
EMMONS, LH., 1984. Geographic variation in densities and diversities of non-flying mammals in Amazon. Biotropica, vol. 16 , no. 3, p. 210-222.

FONTAINE, R., 1980. Observations of the foraging association of Doublé-toothed Kites and white-faced capuchin monkeys. Auk, vol. 97, no. 1, p. 94-98.

GREENLAW, JS., 1967. Foraging behavior of the Doubletoothed Kite in association with white-faced monkeys. Auk, no. 4, p. 296-597.

HAYMANN, EW., 1992. Associations of tamarins (Saguinus mystax and Saguinus fuscicolis) and Double-toothed Kites (Harpargus bidentatus) in Peruvian Amazonica. Folia Primatologica, vol. 59, no. 1, p. 51-55.

HERNÁNDEZ-CAMACHO, J. and DEFLER, TR., 1991. Algunos aspectos de la conservación deprimates no-humanos en Colombia. In SAAVEDRA, CJ., MITTERMEIER, RA. and SANTOS, IB. (Eds.). La Primatología en Latinoamérica. Washington: World Wildlife Fund. p. 67-100.

HERSHKOVITZ, P., 1977. Living new world monkeys (Platyrrhini): with an introduction to primates. Chicago: The University of Chicago Press. (vol. 1).

International Union for Conservation of Nature - IUCN, 2009. IUCN Red List of Threatened Species. Version 2009.1. Cambridge: IUCN. Available from: <www.iucnredlist.org >. Access in: 24/06/2009.

IWANAGA, S., 2004. Levantamento de mamíferos diurnos de médio e grande porte no Parque Nacional do Jaú: resultados preliminares. In BORGES, SH., IWANAGA, S., DURIGAN, CC. and PINHEIRO, MR. (Eds.). Janelas para a Biodiversidade no Parque Nacional do Jaú: uma estratégia para o estudo da biodiversidade na Amazônia. Manaus: Fundação Vitória Amazônica. p. 195-207.

PALÁCIOS, E., RODRÍGUEZ, A. and CASTILlO, C., 2004. Preliminary observations on the ottledface tamarin (Saguinus inustus) on the Lower Río Caquetá, Colombian Amazonia. Neotropical Primates, vol. 12, no. 3, p. 123-126.

SOUZA, LL., QUEIROZ, HQ. and AYRES, JM., 2004. The mottled-face tamarin, Saguinus inustus, in the Amanã Sustainable Development Reserve, Amazonas, Brazil. Neotropical Primates, vol. 12, no. 3, p. 121-122. 